4. Mazzella M, Cotelessa M, Bonassi S et al. (1994) Incidence of type 1 diabetes in the Liguria region Italy - results of a prospective study in a 0 - to 14 -year age-group. Diabetes Care 17: 1193-1196

5. Cerutti F, Cavallo F, DeDonno V, Sacchetti C (1994) IDDM incidence in children 0-14 years of age in Piedmont, Italy. Diabetes Care 17: 1233-1234

6. Kalits I, Podar T (1990) Incidence and prevalence of type 1 (insulin-dependent) diabetes in Estonia in 1988. Diabetologia 33: 346-349

7. Metcalfe MA, Baum JD (1991) Incidence of insulin-dependent diabetes in children aged under 15 years in the British Isles during 1988. BMJ 302: 443-447
8. deBeaufort CE, Michel G, Glaesener G (1988) The incidence of type 1 (insulin-dependent) diabetes mellitus in subjects aged 0-19 years in Luxembourg: a retrospective study from 1977 to 1986. Diabetologia 31: 758-761

9. Levy-Marchal C, Papoz L, de Beaufort C et al. (1990) Incidence of juvenile type 1 (insulin-dependent) diabetes mellitus in France. Diabetologia 33: 465-469

10. Bingley P, Gale EAM (1989) Rising incidence of IDDM in Europe. Diabetes Care 12: 289-295

11. Akerblom HK, Reunanen A (1985) The epidemiology of insulin-dependent diabetes (IDDM) in Finland and Northern Europe. Diabetes 8 [Suppl 1]: 10-16

\section{Is human insulin without effect in the diabetic rat?}

Dear Sir,

It was with great interest that I read the paper by Soulis-Liparota et al. [1], not only because it contains fine experimental work but also because I wonder if they had the same experience as I had recently. Blood glucose levels in their rats were above $30 \mathrm{mmol} / 1$ despite treatment with 2 IU ultralente insulin. In a paper by Rasch [2] a similar insulin dose kept the blood glucose levels below $20 \mathrm{mmol} / \mathrm{l}$. I would like the authors' opinion as to whether they think the type of insulin given had any effect on blood glucose level. I have recently found it impossible to purchase non-human insulin. In the work by Rasch [2] the most efficient insulin was bovine ultralente (Novo Nordisk, Copenhagen, Denmark). I used this insulin for maintaining a blood glucose level of around $20 \mathrm{mmol} / \mathrm{l}$ (Fig.1). Diabetes mellitus was induced with an intraperitoneal injection of streptozotocin $(90 \mathrm{mg} / \mathrm{kg})$ in 24 male Sprague-Dawley rats (weight $140 \mathrm{~g}$ ). Up to a diabetes duration of 33 days their blood glucose level was kept at $19 \mathrm{mmol} / \mathrm{l}$ with a mean dose of one IU of bovine insulin given once a day. Thereafter, 18 animals were changed from bovine to human insulin (Ultratard HM $40 \mathrm{IU} /$ $\mathrm{ml}$; Novo Nordisk). Despite successively increasing the insulin dose to $15 \mathrm{IU}$ per day it was not possible to lower the blood glucose levels below $22 \mathrm{mmol} / \mathrm{l}$. In contrast the blood glucose level in the six bovine-insulin-treated rats was maintained with a dose of 2 IU per day.

The experiment leads to the following questions: is it possible to purchase non-human insulin? Is the human insulin without effect in the rat?

Yours sincerely,

O. Torffvit

\section{References}

1. Soulis-Liparota T, Cooper ME, Dunlop M, Jerums G (1995) The relative roles of advanced glycation, oxidation and aldose reductase inhibition in the development of experimental diabetic nephropathy in the Sprague-Dawley rat. Diabetologia 38: 387-394

2. Rasch R (1979) Control of blood glucose levels in the streptozotocin diabetic rat using a long-acting heat-treated insulin. Diabetologia 16: 185-190

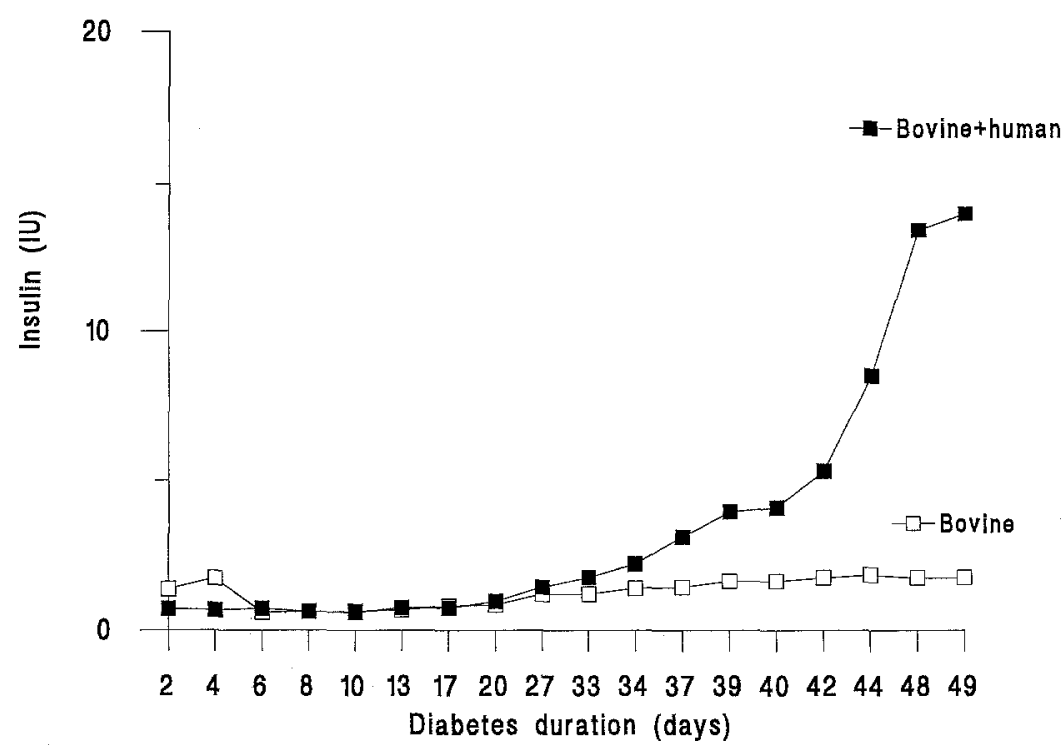

Fig.1. Insulin doses (IU/day) in insulin-treated diabetic rats. Bovine $=$ Bovine ultralente treated rats $(n=6)$ and bovine + human = initially for 33 days bovine-insulin-treated rats, thereafter switched to human insulin (Ultratard) 


\section{Response from the authors}

\section{Dear Sir,}

We thank Dr. Torffvit for his query regarding the efficacy of different forms of insulin in the rat. Our own study has not specifically addressed this issue. However, over the last 10 years, we have used different doses of both bovine and human ultralente insulins in rats with both short- and long-term experimental diabetes. We were unable to locate a direct comparison of bovine and human insulin in rats although this issue has been addressed in a range of human studies. These studies have suggested that human ultralente insulin, although similar in potency to bovine insulin, has a shorter duration of action in $\operatorname{man}[1,2]$.

In our previous animal studies, we used heat-treated bovine Ultralente insulin and as noted by Dr. Torffvit, we achieved blood glucose levels of less than $22 \mathrm{mmol} / \mathrm{l}$ with a dose of $2 \mathrm{IU} /$ day [3]. However, as indicated previously, there was a heterogeneous response among the diabetic rats. In our more recent studies, using human ultralente insulin, the dose of $2 \mathrm{IU} /$ day was not associated with blood glucose levels greater than $20 \mathrm{mmol} / 1$ [4]. However, the possibility that human insulin is ineffective in rats is unlikely since in a recent study using human insulin administered via silastic implants, we were able to achieve euglycaemia [5].

Another factor which needs to be considered relates to the severity of the diabetes that is induced by streptozotocin. This relates not only to the susceptibility of the individual rat strain to streptozotocin but also to the dose and mode of administration of streptozotocin [6]. In our studies, streptozotocin was given at a dose of about $45-60 \mathrm{mg} / \mathrm{kg}$ whereas Dr. Torffvit gave a

Corresponding author: Dr. T.Soulis-Liparota, Department of Medicine, Heidelberg Repatriation Hospital, West Heidelberg, Victoria 3081, Australia much higher dose of $90 \mathrm{mg} / \mathrm{kg}$. Our own experience involving serial sampling of diabetic animals for blood glucose levels has indicated marked temporal variability of glucose control within individual animals. This emphasises the importance of using glycated haemoglobin in long-term studies in diabetic rats. Finally, it is possible to obtain both bovine insulin (Ultralente MC beef) and human insulin (Ultratard Human Monocomponent) from Novo Nordisk (Copenhagen, Denmark).

Yours sincerely,

T. Soulis-Liparota, M. Cooper, M. Dunlop, G. Jerums

\section{References}

1. Hildebrand TP, Berger A, Volund AA, Kuhl C (1985) The subcutaneous absorption of human and bovine ultralente insulin formulations Diabet Med 2: 355-359

2. Owens DR, Vora JP, Heding LG et al. (1986) Human, porcine and bovine ultralente insulin: subcutaneous administration in normal man. Diabet Med 3: 326-329

3. Allen TJ, Cooper ME, O'Brien R, Bach L, Jackson B, Jerums $G$ (1990) Glomerular filtration rate in streptozotocininduced diabetic rats. Role of exchangeable sodium, vasoactive hormones and insulin therapy. Diabetes 39: 1182-1190

4. Soulis-Liparota T, Cooper ME, Dunlop M, Jerums G (1995) The relative roles of advanced glycation, oxidation and aldose reductase inhibition in the development of experimental diabetic nephropathy in the Sprague-Dawley rat. Diabetologia 38: 387-394

5. Cooper ME, Rumble J, Komers R; He-Cheng D, Jandeleit $\mathrm{K}$, Sheung-To C (1994) Diabetes-associated mesenteric vascular hypertrophy is attenuated by angiotensin-converting enzyme inhibition. Diabetes 43: 1221-1228

6. Somani P, Singh HP, Sairii RK, Rabinovitch R (1979) Streptozotocin-induced diabetes in the spontaneously-hypertensive rat. Metabolism 28: 1071-1077

\section{Class I HLA is associated with age-at-onset of IDDM, while class II HLA confers susceptibility to IDDM}

\begin{abstract}
Dear Sir,
Among patients with insulin-dependent diabetes mellitus (IDDM), heterogeneity is observed for age of the disease onset. Previous reports in different ethnic groups suggested that the heterogeneity in age-at-onset of IDDM may be determined by gene(s) in the HLA region $[1-5]$. To investigate the relative contribution of HLA loci to genetic susceptibility to IDDM and to heterogeneity in IDDM, we typed 10 loci in the HLA region, i.e. HLA-A, B, C, DR, DQA1, DQB1, TAP1, TAP2, LMP2 and HSP70-2 genes.

Eighty-one unrelated patients with IDDM and 71 healthy control subjects were studied. Mean \pm SD age-at-onset of the disease was $20.8 \pm 13.8$ years (range: $0-59$ years). The patients were divided into tertiles according to their age-at-onset of IDDM, such that each group contained an equal number of pa-
\end{abstract}

Corresponding author: Dr. H. Ikegami, Department of Geriatric Medicine, Osaka University Medical School, 2-2 Yamadaoka, Suita, Osaka 565, JAPAN tients: early-onset (0-12 years), intermediate-onset (1324 years), and late-onset ( $>25$ years). HLA-A, HLA-B, HLA-C and HLA-DR antigens were serologically typed. HLA-DQA1 and DQB1 alleles and polymorphism of TAP1, TAP2 and LMP2 genes were determined by PCR-RFLP methods as reported previously $[1,6,7]$. A Pst I polymorphism of heat shock protein (HSP) 70-2 gene was examined by the Southern blot hybridization method with probe (American Type Culture Collection, Rockville, Md., USA) [8]. The significance of the difference in allele frequencies was determined by the chi-square test or Fisher's exact test, with corrected $p$ values $(p c)$.

As reported previously [1], susceptibility to IDDM was strongly associated with class II HLA loci. HLA-DR9, DQA $1 * 0301$, DQB $1 * 0303$ and DQB $1 * 0401$ were positively associated with IDDM, whereas HLA-DR2, DQA1*01, DQA $1 * 0103, \mathrm{DQB} 1 * 0501$ and DQB $1 * 0601$ were negatively associated. In contrast to the strong association of class II alleles with disease susceptibility, class II alleles showed little effect on the age of disease onset. Instead, class I loci were strongly associated with the age-at-onset of IDDM. Significant heterogeneity was observed in the distribution of B7 and $\mathrm{Cw} 7$ alleles. The frequency of $\mathrm{B} 7$ was highest in early-onset patients $(35 \%)$, was $4.4 \%$ in the intermediate age at-onset group, and none of the late-onset patients had this allele $\left(\chi^{2}=15.0,2\right.$ degrees of freedom $[d f]$, uncorrected $p=0.0006$, 